\title{
MEANINGFUL INEQUALITIES
}

\author{
GRAHAME BENNETT
}

Abstract. The fundamental Theorem on Means serves to "explain" many recently published inequalities, and even to suggest new versions. Our aim here is to explore the possibilities.

Mathematics subject classification (2000): $26 \mathrm{D} 15$.

Key words and phrases: Alzer's inequality, golden mean, Martins' inequality.

\section{REFERENCES}

[1] H. Alzer, On an inequality of Minc and Sathre, J. Math. Anal. Appl. 179 (1993), no. 2, 396-402.

[2] H. AlzER, Refinement of an inequality of G. Bennett, Discrete Math. 135 (1994), no. 1-3, 39-46.

[3] G. BENNETT, Lower bounds for matrices, II, Canad. J. Math. 44 (1992), 54-74.

[4] G. Bennetr, Factorizing the classical inequalities, Mem. Amer. Math. Soc. 120 (1996), no. 576, viii $+130 \mathrm{pp}$.

[5] G. BenNetT, Meaningful sequences, Houston J. Math. 33 (2007), no. 2, 555-580.

[6] G. BENNETT, Meaningful sequences and the theory of majorization, to appear in Houston J. Math.

[7] I. BRnetić AND J. PEČARIĆ, Comments on some analytic inequalities, J. Inequal. Pure Appl. Math. 4 (2003), no. 1, Article 20, 5 pp. (electronic).

[8] T.H. Chan, P. GAO AND F. QI, On a generalization of Martins' inequality, Monatsh. Math. 138 (2003), no. 3, 179-187.

[9] C.-P. CHEN AND F. QI, Extension of an inequality of H. Alzer for negative powers, Tamkang J. Math. 36 (2005), no. 1, 69-72.

[10] C.-P. CHEN AND F. QI, Generalizations of an inequality of Alzer for negative powers, Tamkang J. Math. 36 (2005), no. 3, 219-222.

[11] C.-P. ChEN AND F. QI, Note on Alzer's inequality, Tamkang J. Math. 37 (2006), no. 1, 11-14.

[12] C.-P. Chen, F. Qi AMd S.S. Dragomir. Reverse of Martin's inequality. Aust. J. Math. Anal. Appl. 2 (2005), no. 1, Article 2, 5 pp. (electronic).

[13] S.S. DRAGOMIR AND J. VAN DER HOEK, Some new analytic inequalities and their applications in guessing theory, J. Math. Anal. Appl. 225 (1998), no. 2, 542-556.

[14] N. Elezović And J. PeČArić, On Alzer's inequality, J. Math. Anal. Appl. 223 (1998), 366-369.

[15] B.-N. GUO AND F. QI, Inequalities and monotonicity of the ratio for the geometric means of a positive arithmetic sequence with arbitrary difference, Tamkang J. Math. 34 (2003), no. 3, 261-270.

[16] B.-N. GUO AND F. QI, Monotonicity of sequences involving geometric means of positive sequences with monotonicity and logarithmical convexity, Math. Inequal. Appl. 9, (2006), no. 1, 1-9.

[17] G.H. Hardy, J.E. Littlewood AND G. Pólya, Inequalities, 2nd edition, Cambridge University Press, Cambridge, 1967.

[18] J. KuANG, Some extensions and refinements of Minc-Sathre inequality, Math. Gaz. 83 (1999), 123-127.

[19] A.W. Marshall AND I. Olkin, Inequalities: Theory of Majorization and its Applications, Academic Press, New York, 1979.

[20] J.S. MARTINS, Arithmetic and geometric means, an application to Lorentz sequence spaces, Math. Nachr. 139 (1988), 281-288.

[21] V. MASCIONI, A sufficient condition for the integral version of Martins' inequality, J. Inequal. Pure Appl. Math. 5 (2004), no. 2, Article 32, 3 pp. (electronic).

[22] H. Minc AND L. SATHRE, Some inequalities involving $(r !)^{\frac{1}{r}}$, Proc. Edinburgh Math. Soc. (2) 14 $(1964 / 5), 41-46$. 
[23] F. QI, Generalization of H. Alzer's inequality, J. Math. Anal. Appl. 240 (1999), no. 1, 294-297.

[24] F. QI, AN Algebraic IneQuality, J. Inequal. Pure Appl. Math. 2 (2001), no. 1, Article 13, 3 pp. (electronic).

[25] F. QI, Inequalities and monotonicity of the ratio of the geometric means of a positive arithmetic sequence with unit difference, Internat. J. Math. Ed. Sci. Tech. 34 (2003), no. 4, 601-607.

[26] F. QI, Inequalities and monotonicity of the ratio for the geometric means of a positive arithmetic sequence with unit difference, Austral. Math. Soc. Gaz. 30 (2003), no. 3, 142-147.

[27] F. QI AND L. DEBNATH, On a new generalization of Alzer's inequality, Internat. J. Math. Math. Sci. 23 (2000), no. 12, 815-818.

[28] F. QI AND B.-N. GUO, An inequality between ratio of the extended logarithmic means and ratio of the exponential means, Taiwanese J. Math. 7 (2003), no. 2, 229-237.

[29] F. QI AND B.-N. GUO, Monotonicity of sequences involving geometric means of positive sequences, Nonlinear Funct. Anal. Appl. 8 (2003), no. 4, 507-517.

[30] F. QI AND Q.-M. LuO, Generalization of H. Minc and L. Sathre's inequality, Tamkang J. Math. 31 (2000), no. 2, 145-148.

[31] J. SÁNDOR, On an inequality of Alzer, J. Math. Anal. Appl. 192 (1995), no. 3, 1034-1035.

[32] J.S. UME, An elementary proof of H. Alzer's inequality, Math. Japonica 44 (1996), 521-522.

[33] J.S. UME, An inequality for a positive real function, Math. Inequal. Appl. 5 (2002), no. 4, 693-696.

[34] J.S. UME, Z. LIU AND J.N. MCDONALD, A simple proof of generalized Alzer's inequality, Indian J. Pure Appl. Math. 35 (8) (2004), 969-971.

[35] Z. XU AND D. XU, A general form of Alzer's inequality, Comput. Math. Appl. 44 (2002), no. 3-4, 365-373.

[36] S.-L. Zhang, C.-P. ChEN AND F. QI, Continuous analogue of Alzer's inequality, Tamkang J. Math. 37 (2006), no. 2, 105-108. 